\title{
THE DESALTING OF URINES PRIOR TO AMINO ACID CHROMATOGRAPHY
}

\author{
Sergeant T. WILLIAMSON, \\ A.I.M.L.T., R.A.M.C. \\ Royal Army Medical College, Millbank
}

\section{Introduction}

THE need for a simple and inexpensive method for identifying urinary amino acids has been fulfilled to date by the use of paper chromatography: Before the urine can be chromatographed for amino acids, inorganic ions and large neutral molecules such as proteins must be removed. If left in solution they will seriously impair the spot separation. Several methods of effecting deionisation have been described and fall into three main categories:

\section{Organic solvent extraction}

Verghese and Ramakrishnan (1957) described a method in which urine is evaporated to dryness and the amino acids extracted from the residue with a mixture of phenol and butanol. This becomes a lengthy procedure since dessication over-night is involved.

\section{Electrolytic deionisation and dialysis}

These two methods, described respectively by Consden et al (1947) and Wood (1956) are very efficient, but require equipment not readily available. They are expensive, taking into account the fact that since the Army is a relatively healthy community, identification of urinary amino acids is a comparatively uncommon request.

\section{Ion exchange resins}

Smith (1958) indicated how a cation exchange resin could be used to adsorb inorganic ions and amino acids from urine followed by selective elution, concentration and chromatography of the amino acids.

Thus a method for deionising urines based on this third category has been found suitable and is subsequently described.

\section{Materials and Methods}

This method depends on the fact that amino acids in solution are capable of acting as weak bases or weak acids.

They contain both basic $\left(-\mathrm{NH}_{2}-\right)$ and acidic $(-\mathrm{COOH}-)$ radicles.

Thus is acid solution they act as weak bases and are adsorbed onto the resin in a like manner to the inorganic cations.

$$
\text { R. } \mathrm{CHNH}_{2} \mathrm{COOH}+\mathrm{H}^{+} \mathrm{Cl}^{-} \text {R. } \mathrm{CHNH}_{3}^{+} \mathrm{COOH}+\mathrm{Cl}^{-}
$$

Slightly acid urine is passed through the cation exchange resin "ZEOKARB 225": Proteins and anions are washed out of the column and the amino acids eluted with ammonia, leaving the inorganic cations absorbed on the resin. "ZEOKARB 225 " is a 
stable sulphonated polystyrene resin, operational over a wide $\mathrm{pH}$ range and is used for this purpose at a mesh size of 52-100. It is supplied by British Drug Houses in the sodium form so conversion to the hydrogen or acid form is necessary.

This is done by soaking a quantity of resin in twice its volume of warm 10 per cent $\mathrm{v} / \mathrm{v}$ hydrochloric acid. The resin settles out and the hydrochloric acid plus any remaining floating particles is decanted to waste. This is repeated and followed by three similar washings in double distilled water. The resin may be stored at this stage in an airtight container, preferably polythene, as an aqueous slurry.

A column of $25 \mathrm{ml}$. of resin is set up in a burette after first plugging the bottom with a small wad of glass wool. Any bubbles trapped in the column may be disturbed by back flushing with water from a high reservoir connected to the nozzle. The water standing on the column is allowed to run away and the surface of the resin plugged with another glass wool plug. Cotton wool is unsatisfactory. At no time during or after use is the resin allowed to dry.

The deionisation of the urine is carried out as follows:-

$5 \mathrm{ml}$. of slightly acid filtered urine ( $\mathrm{pH}$ about 6.0) are pipetted onto the resin and allowed to percolate into the column. This is followed by $30-35 \mathrm{ml}$. of double distilled water which is allowed to run to waste. $30 \mathrm{ml}$. of $3 \mathrm{~N}$ ammonia are poured into the column. As the ammonia travels downwards the resin will be seen to change colour from a light to a dark amber. When the ammonia approaches the nozzle the drops are allowed to fall onto red litmus paper in a $10 \mathrm{ml}$. measuring cylinder. On the litmus paper changing colour $1 \mathrm{ml}$ of the eluate is measured and discarded. The remaining eluate is collected. The ammonia remaining in the column is displaced with distilled water and collected. The total eluate should measure about $25 \mathrm{ml}$. This is evaporated down to $1 \mathrm{ml}$. on a boiling water bath or over a low bunsen flame, then cooled. This drives of the ammonia and concentrates the original sample content five times. The eluate can then be spetted onto the chromatography paper.

\section{Results}

Recovery experiments were carried out using solutions of amino acids in electrolyte solutions, in normal and known abnormal samples of urine. In between samples the resin column was recharged with 5 per cent $\mathrm{v} / \mathrm{v}$ hydrochloric acid and washed with double distilled water. The subséquent chromatography was carried out " two way,", using Smith's n butanol/acetic/water and phenol/ammonia solvents with ninhydrin or isatin in pyridine and acetone as locating reagents.

It was found that all amino acids likely to occur in urine, normal and abnormal, were recovered from the column with the one exception of taurine. This was either conpletely absent or gave a very faint spot, depending on its original coneentration.

The concentration of ammonia for elution was found to be critical $2 \mathrm{~N}$ ammonia gave excellent, discrete spots but failed to elute arginine. $4 \mathrm{~N}$ ammonia gave the best recovery of arginine but the diffuse spots suggested that inorganic cations were also being eluted. $3 \mathrm{~N}$ ammonia gave a reasonable recovery of arginine with good spots and is used routinely.

This method has been used routinely for amino acid chromatography of ùrines at the Royal Army Medical College for the past four years and has proved satisfạctory. 


\section{Summary}

Deionising methods for urine amino acid chromatography are briefly reviewed with the purpose of elucidating a satisfactory method using simple equipment suitable for routine use.

A method suggested by Smith (1958) using an ion exchange resin has been investigated, modified and found satisfactory.

\section{REFERENCES}

Consden, R., Gordon, A. H. and Martin, A. J. P. (1947). Biochem. J. 41, 590.

Sмiтн, I. (1958) Chromatographic and Electrophoretic Techniques. Vol. 1, ch 3. Heinemann.

WooD, T. (1956). Biochem. J. 62, 611.

Verghese, N. and Ramakrishnan, P. N. (1957). J. Clin. Path. 10, 104.

To the Army

Endocrinology

Oto-Rhino-Laryngology

To the Army in Scotland

Thoracic Surgery.

To the Queen Alexandra Military Hospital

Oto-Rhino-Laryngology - Mr. R. A. Williams, M.A., M.B., B.Chir., F.R.C.S, as from 25th March, 1966.

- Dr. J. D. N. Nabarro, M.D., F.R.C.P., in succession to Dr. A. W. Spence who has retired.

Mr. G. H. Bateman, M.A., B.M., B.Ch., F.R.C.S., in succession to Mr. Myles L. Formby who has retired.

- Mr. Andrew Logan, M.A., M.B., F.R.C.S., F.R.C.S. (Edin.), in succession to Mr. B. W. Dick who has retired.

\section{Honorary Consultants}

